\title{
Social and Environmental Accounting: A Reflection of Indonesian Firms' Involvement
}

\author{
Aprianto Aprianto \\ Faculty of Economics and Business \\ University of Muhammadiyah Palemban, Indonesia \\ Email: fitriya.fauzi@ymail.com
}

Received: May 05, 2016 Accepted: June 05, 2016 Published: June 11, 2016

doi:10.5296/ijafr.v6i1.9512 URL: http://dx.doi.org/10.5296/ijafr.v6i1. 9512

\begin{abstract}
The economic crisis in Indonesia prolonged since 1997 has boosted the nation in the position of multi-dimensional crisis in almost all aspects of life. The increasing number of victims of layoffs, high unemployment, declining per capita income and purchasing power and ultimately it leads to the increase number of society that is below the poverty line. The Government efforts to convince the international investor should be focused on the social and political stability, and security that may assure investors. The economic crisis and social crisis in Indonesia are still into two sides that cannot be separated, and the effect on the business world is very significant, so that companies that want to run business operations in Indonesia cannot escape from social problems faced by this nation. Social problems for companies is not the main target, because many other factors such as investment, financing, production, marketing directly related to the normal activity of a company, but a consequence of the interaction between the company and the environment which is undergoing a social crisis becomes unavoidable. Social Accounting is still the pros and cons in the accounting world Indonesia, until now given the presence of pros and cons about the extent to which the company should be accountable to their social environment. The practice of social disclosure firms in Indonesia is still very low because the company allegedly oriented to the Shareholder and debt holders only. The role and application of social accounting need to be developed in Indonesia in order to encourage the creation of corporate social responsibility that are expected to minimize the social problems faced by business entities in Indonesia, so that the healthy investment climate and enduring economic stability.
\end{abstract}

Keywords: Loan loss provisions, Assets, IFRS, CBN, Deposit money bank, Nigeria. 


\section{Introduction}

Social accounting (social Accounting) in Indonesia to grow following the demand of the expansion of corporate responsibility. Social accounting cannot be separated from the social environment in which the entity is located, so that the interaction between the two needs to be accommodated in the techniques and methods of accounting. This paper discusses the theoretical basis of social accounting and its implementation in Indonesia with the conclusion that the application of social accounting in Indonesia is still very low and the role of social accounting to be relevant as a solution to social problems faced by the company in Indonesia.

Philosophical shift in organizational management business entities changed from the classical management view to modern management, especially in some industrialized countries such as America and Europe has resulted in a new orientation on corporate responsibility. The views Management classic on corporate responsibility that is only oriented to shareholders and creditors to achieve the level of maximum profits has shifted to the concept of management of modern, where the orientation of the company in achieving maximum profits need to be linked to the social responsibility of the company towards a balance between the demands of the owners of the company, the needs of employees, customers, suppliers, the environment and the general public, because in the view of modern management company to run its operations should interact with the social environment and economic resources used by the company are all derived from the social environment in which they operate. Therefore the company as a business organization should be able to respond to what is demanded by the social environment, so that business entities and social entities can interact and communicate in the common interest.

Along with the development of the concept of the management, the accountant also discuss how the issues of social responsibility can be adapted within the scope of accounting (Hines, 1988) in Azhar infallible, (1991), so that the main purpose of financial reporting in order to provide information to flow to shareholders and creditors be joined also shifted towards the tendency that the need for reporting that are outside the company's organization (externalities) in order to provide Opera- to groups of outsiders interested in the company. Based on the description above can be understood that the basic idea underlying the need for the development of social accounting social (Accounting), in general, is actually a claim against the expansion of corporate responsibility.

Since the decade of the 70s, this externality problem continues to be an important issue among the accounting profession. Some writers like Estes (1973); Bowman and Mason (1976); K.Most (1977); Carrol AB (1984); Henderson (1984) and Chua (1990) in Sawardjono (1991), illustrates some concrete examples that can be considered as an externality, among others, as reported number of employees, healthcare, information about the prevention of environmental pollution, quality standards, packaging environmentally friendly products, distribution of educational scholarships, internship opportunities, job training for students and social care to people around the industry. Another important issue which is an issue among accountants in connection externally is about how far companies should be responsible for the socio-economic whole, and how the accounting treatment was appropriate to describe 


\section{Macrothink \\ International Journal of Accounting and Financial Reporting \\ ISSN 2162-3082 \\ 2016, Vol. 6, No. 1}

transactions that occur between companies and the social environment.

Harahap $(1988 ; 1993 ; 2001)$ suggested that the question of whether the company needs to have a social responsibility or not, until now still a scientific debate in the capitalist economic system. Furthermore Harahap (2002) stated that this phenomenon is a form of capitalist awareness on corporate social responsibility through the presentation of accounting information. Pros and cons can certainly be understood as groups that support or not support had interests and arguments of each.

In Indonesia alone, social accounting issues is not new, accounting experts in Indonesia has also conducted the analysis and study of the possibility of applying social accounting in Indonesia (Harahap, 1988); see also Sudibyo (1988); Hadibroto (1988) in Suadi (1988), only social accounting became less popular because of the possibility of companies in Indonesia utilizing the annual report only as a report to the Shareholders and Debt holders or as information for potential investors (Utomo, 2000).

An analysis conducted by Sudibyo (1988) in Suadi (1988) concluded that there are two things that become obstacles difficulty of the application of social accounting in Indonesia, namely (1) the lack of social pressures that require corporate social responsibility, and (2) low awareness companies in Indonesia on the importance of social accountability.

Meanwhile articles written by Harahap (1988) we need to develop the concept of SocioEconomic Accounting (SEA) in Indonesia because it is closer to the philosophy of the Indonesian nation, the development of business environment so rapidly today has encouraged companies in Indonesia moving towards awareness of the importance social accountability, so that needs to be analyzed back in the application of accounting social circumstances and economic conditions in Indonesia today.

\section{Definition of Social Accounting}

The term Social Accounting (Social Accounting) is not really a standard term in accounting. Experts accounting be made of each term to describe the transactions between the company and its environment. Ramanathan (1976) in Suadi (1988) use the term Social Accounting and defines it as the process of selecting the variables that determine the level of corporate social achievements both internally and externally. Lee D Parker (1986) in Suadi (1988) uses the term Social Responsibility Accounting, which is a branch of accounting knowledge. Meanwhile Belkoui in Harahap (1993) makes a terminology Socio Economic Accounting (SEA), which means the process of measurement, regulation and disclosure of the impact of exchange between the company and its environment.

Hadibroto (1988); Sudibyo (1988) and accounting experts in Indonesia to use the term accounting social accountability (APS) as an accounting that requires a report on the implementation of corporate social responsibility. Hendriksen (1994), describes the social accounting as a statement of purpose, a series of social concepts and methods of measurement, reporting structures and communication of information to the parties concerned. Statement Hendriksen (1994) provides an overview of the fundamental relationship between the concepts of social accounting with information generated, so 
concretely that information can be considered in the decision making.

Based on the explanation above, basically the definition given by experts on accounting for social accounting has the same characteristics, as suggested by Ramanathan (1976) in Suadi (1988), namely Accounting social closely related to the problem: (1) The impact assessment social activity of business entities, (2) measuring the activity (3) to report corporate social responsibility, and (4) internal and external information systems on an assessment of the company's resources and socioeconomic impact.

\section{The Purpose of Social Accounting}

The purpose of social accounting according to Hendriksen (1994) is to provide information that enables the influence of the company's activities on the community can be evaluated. Ramanathan (1976) in Suadi (1988) also outlines the three objectives of social accounting, namely: (1) identify and measure the social contribution of net periodic a company, which includes not only the benefits and social costs in internalize enterprising, but also arises from externalities affecting segments of different social, (2) help determine whether strategies and practices of companies that are directly affecting the relativity of resources and the status of individuals, communities and segments of the social is consistent with the priority given social broadly on the one hand and individual aspiration on the other hand, (3) provide the optimal way, to all social groups, relevant information about its objectives, policies, programs, strategies and contribution of a company to the social objectives of the company.

Based on the objectives of social accounting described above can be understood that the social accounting role and function as a business language that accommodates the social problems faced by the company, so outposts social costs incurred to the community can support the operations and achievement of long term goals of the company.

\section{Measurement of Social Accounting}

In the exchange that occurs between the company and its social environment, there are two impacts arising i.e. positive or also called social benefits (Social benefits) and the negative effect which is called social sacrifice (Social Cost). The problem that arises is how to measure both the impact. According Harahap (1993), social accounting measurement problem is complicated, because when compared to regular transactions that can be recorded directly and affect the financial position, then the social accounting must first be measured positive impacts and negative impacts caused by the company.

Furthermore, Harahap (1993) outlines some of the methods commonly used in the measurement of social accounting, namely; (1) Using Assessment to calculate the opportunity cost approach; (2) Using the questionnaires; (3) Using the relationship between the loss of mass demand for individual items in calculating the loss of society; (4) Using the reaction of the market to determine prices.

Zulfikar (1987) in Sonhadji (1989) provides some measurement techniques can be used, among others; (1) Assessment of replacement, that is, if the value of something cannot be directly determined, it can be estimated with a replacement value; (2) Technical survey, which includes ways to get information from the community about the company's social 
activity measurement; (3) The cost of repair and prevention, namely the repair costs incurred by the company in relation with the social environment; (4) Assessment of an independent appraiser, which provides a right to outsiders to measure the social activity of the company; (5) The court ruling, by a decision that has the force of law.

Empirically several companies in the US such as IBM, Chase Manhattan corporation, Bank of Minneapolis has introduced a quantitative social information in its financial statements, which showed the measurement of social impact measurement practices for their company (Sonhadji, 1989)

\section{Reporting, Disclosure (Disclosure) Social Accounting}

According Belkoui (1985), quoted by Harahap (1993), reporting on social accounting, means containing information regarding a positive or negative impact caused by the company. This reporting according Belkoui (1980) in Sawardjono (1991) is based on whether or not the information is relevant, and this depends on the relevance of the information consumers. According Sawardjono (1991), an increased need for this information can be seen from the increasing number of companies that have reported their social responsibilities. In developed countries such as America, Canada, Britain, Australia and Japan, this reporting is already a common thing. Estes (1976) in Sondhaji (1989) describes the social accounting reporting practices consisting of (1) The practice is simple, namely the report consists of a description of social accounting that is not accompanied by quantitative data, both units of money or other units; (2) Practice more advanced, that the report consists of a description of social accounting and accompanied by quantitative data; (3) Practice the most advanced, namely in the form of qualitative statements, the company also has the report in the form of balance.

Furthermore, with the development of the capital market, companies to report and disclose social activities to provide information to shareholders, potential investors and external parties (stakeholders) others who are also interested. The disclosure practices of social (social disclosure) in the annual report the company has carried out country western European countries, the USA, Australia, New Zealand, Singapore and Malaysia. This situation helped encourage companies to voluntarily disclose for each period of the social environment, so as to show to the parties interested in the company's annual report to explain social awareness and sensitivity of a business entity.

In United States practice of social disclosure has been started since 1970 and to date has been a lot FASB recommends more specific about reporting standards externalities. Davidson (1993) provides examples of FAS No. 5 governing the presentation of the social impact, especially on the environmental impact. Davidson (1993) a director who handles environmental affairs at the Ernst and Young consulting Washington, said that the current SEC (stock exchange commission) has implemented a review for companies that disclose environmental impacts in their annual reports. However, the disclosure of social information in the United States today still kerelaaan (Voluntary disclosure) and is not an obligation (Mandatory disclosure), but the tendency is the express company social activities are to describe further about the pursuit of a company to perform a task - social function. 


\section{MInstitute Mach $^{m}$}

International Journal of Accounting and Financial Reporting

ISSN 2162-3082 2016, Vol. 6, No. 1

Studies conducted abroad show that in England Ince and Davut (1997), Eric Tsang and WK (1998) in Singapore, Hackson and Milne (1996) in New Zealand, Adam et.al (1997) in six European countries (France, Germany, Switzerland, England, and the Netherlands) and research Andrew et.al (1989) in Malaysia and Singapore demonstrate corporate social disclosure has become a common thing done with great emphasis that the company disclose more social than the smaller companies. Moreover, Deegan and Gordon (1991) in Heny and Murtanto (2001) suggested that most of the disclosures made by companies are still qualitative, and the tendency of enterprise information stated positive than negative information.

\section{Review of Implementation of Social and Environmental Accounting in Indonesia}

The economic crisis in Indonesia prolonged since 1997 has boosted the nation in the position of multi-dimensional crisis in almost all aspects of life. Especially when viewed in greater detail on the economic aspects, the economic fundamentals (investment, production and distribution) paralyzed, causing the bankruptcy of the corporate world, the increasing number of victims of layoffs, high unemployment, declining per capita income and purchasing power, and ultimately lead to the increase number of figures that are below the poverty line. With the high rate of interest over sixty percent at the height of the current crisis, it is very difficult for banks to roll credits, plus stricter regulation of liquidity in banking sector as a result of the accumulation of bad loans Group conglomerate and subsidiary of troubled banks encouraged the government to liquidate, restructuring and bank recapitalization.

According to Ramli (1998), the economic crisis that swept the nation Indonesia resulted in the emergence of a variety of things that are uncertain, so that the economic indicators such as interest rates, inflation, exchange rate, stock price index, and so are particularly vulnerable to the issues social. This proves that the social and political aspects can invite market sentiment on economic instability. These conditions must be devastating for a map of the business and investment climate in Indonesia, especially to gain the confidence of foreign investors who want to invest in Indonesia.

Government efforts to convince the international community will be social and political stability and security have not shown signs of meaning because it is not supported by the data and the actual fact, even some foreign investors planning to do business relocation and investment to other Southeast Asian countries such as Vietnam, Thailand and Cambodia is considered to be more conducive to invest like the case of a shoe factory in Tangerang, Banten and Sidoarjo, East Java. Therefore, it can be concluded that the economic crisis and social crisis in Indonesia is still into two sides that cannot be separated, and the effect on the business world is very significant, so that companies that want to run business operations in Indonesia cannot escape from social problems faced by this nation. Social problems for companies is not the main target, because many other factors such as investment, financing, production, marketing directly related to the normal activity of a company, but a consequence of the interaction between the company and the environment which is undergoing a social crisis becomes unavoidable. Table. 1 will recapitulate some of the examples of the social problems faced by the company in Indonesia. 


\section{Macrothink \\ International Journal of Accounting and Financial Reporting \\ ISSN 2162-3082 \\ 2016, Vol. 6, No. 1}

Table 1.Summary of social responsibility problems in Indonesia

\begin{tabular}{|c|c|c|c|}
\hline No & Company & Location & Social Case \\
\hline
\end{tabular}

01. PT.Ajinamoto Indonesia

Jakarta

02. Few of papers and pulp company in Riau

03. PT.Maspion Indonesia Sidoarjo

Surabaya

JawaTimur

04. PT.Telkom Indonesia

05.

PT. BCA

06. PT.KeretaApi Indonesia

Jakarta

Jakarta

Kediri

JawaTimur

07. Bank Internasional .Indonesia (BII)
Withdrawal distribution, marketing, and production activities for certification of halal by the MUI

Protests from the local community in respect of industrial waste and environmental problems

Problems demo employee labor and welfare issues

United Employees (Sekar) PT.Telkom refuse the sale Division

IV To PT.Indosat

Unions reject divestment of $\mathrm{BCA}$ shares

Unions reject the return of the Board of Directors of time, because they are responsible for some cases of railway accidents that occurred in Indonesia

Employee claims on salaries, wages and employee welfare improvement

Mass Strike employees demanding improved salaries and welfare of workers.

\section{Source : Review berbagaisumber}

A series of other data is actually much more about the social problems faced by FDI and domestic investment in Indonesia. These figures further show how the business world is very vulnerable to a variety of social problems. Some cases rise of workers' demonstrations, 


\section{MInstitute Mach $^{m}$}

International Journal of Accounting and Financial Reporting

ISSN 2162-3082 2016, Vol. 6, No. 1

looting warehouses, office buildings and factories destruction, and the cultivation enterprise because people believe communal land and rights of the people were seized by authorities in the past, reinforce facts about social stability is not conducive.

\section{Role of the Social and Environmental Accounting}

Circumstances as described above require a business entity to be able to access the benefit of the social environment which is followed by the disclosure and reporting to the parties concerned so that produced a report (output) that describes all aspects that can support the viability of an entity. Here, the role of accounting is expected to respond to the social environment as the embodiment of sensitivity and concern for the business entities of their social environment.

Social accounting theoretically requires that companies should look at their social environments, among others, citizens, consumers, workers, government and other parties who may be supporting operational activities due to a shift in corporate responsibility. To get an idea of this company should be able to access their social environment, then to follow up and measure the sensitivity of the company require periodical information, so that this information is expected to contribute to the benefit of all stakeholders (shareholders, stakeholders, debt holders). Social accounting implemented on the basis of social activity carried on by a business entity, then processed based on the principles, methods and concepts of accounting to be disclosed to the parties - the interested parties, and from information generated information users will be able to determine the next policy for social activities and policies for social environment of business entities that run.

Then if the problems of social accounting is associated with the basic principles of good corporate governance (GCG), which became important issues of corporate management nowadays, especially on the principle of Responsibility to talk about how the business entities accountable to stakeholders and the environment, Satyo (2001) writes that the basic principles of good corporate governance (good governance), requires companies to report not only to shareholders, potential investors, creditors and the government alone but also to other stakeholders, such as the general public, consumers, trade unions and employees of the company individually.

Nowadays the demands of managing the company well (GCG) has also become a global issue, where multinational corporations are running operations in Indonesia are always trying to improve transparency and public accountability, so the company is not only concerned with the motives business, but also should pay attention to aspects the environment and society. Harahap (1993) provides an example of how the application of social care companies in Indonesia which is shown in the form of sponsorship participation of religious activity and distribution of educational scholarships.

\section{The Disclosure Practices of Social (Social Disclosure) in Indonesia}

Social disclosure practices for companies in Indonesia who want to express their social environment can be guided by standards that have been issued and regulated by the Indonesian Institute of Accountants, which implicitly have to accommodate it. As stated in 
the Statement of Financial Accounting Standards (SFAS) No. 1 (Revised 1998). Paragraph 9, which reads as follows:

"Companies can also present additional statements such as statements regarding the environment and report value added (value added statement), especially for industries where factors - environmental factors play an important role and for an industry that considers employees as a group of users report plays an important role".

Under SFAS above, firms in Indonesia can report their social activities to be communicated to external parties in the form of reports added value, so it can be understood that the efforts for corporate social responsibility reporting has been accommodated by the accounting profession in Indonesia.To see more social disclosure practices in the company's annual report in Indonesia, accounting researchers have conducted various studies such as that conducted by Utomo (2000); Heny and Murtanto (2001). The results of the research found that companies in Indonesia revealed three major themes in social disclosure, namely labor, product and consumer and social themes.

Research conducted by Utomo (2000) also concluded that social disclosure by companies in Indonesia is still relatively very low, and the company allegedly did not take advantage of the annual report as a medium of communication between the company and other stakeholders. While research Heny and Murtanto (2001) showed that the level of social disclosure in Indonesia is still relatively low at $42.32 \%$. Social disclosure made by companies most commonly found in the notes to the financial statements and the disclosure of the type most widely used is the type of qualitative narrative.

Application of social disclosure in Indonesia is still very low evidenced by the results of Muslims Utomo (2000); Heny and Murtanto (2001) which also indicates that the practice of social accounting in Indonesia is still very low, so that the conclusions of analysis Sudibyo (1988) in Suadi (1988) which states that the awareness of corporate social responsibility in Indonesia is very low to date in general still acceptable to see the empirical evidence for the application of social accounting firms in Indonesia.

Recommendations Harahap (1993) on the need for the development of social accounting in Indonesia is still considered relevant to be able to create a condition of social stability of the social environment of a business entity, so that the necessary awareness and sensitivity of a business entity to the social problems that contributed to the creation of corporate social responsibility in Indonesia.

Thus this paper recommends social disclosure in the company's annual report shall not constitute voluntary disclosure, but can be considered to be a necessity (Mandatory disclosure). Here, the role of the organization and the accounting profession are required to respond to developments in the Indonesian business world environment of ever-changing very quickly. Furthermore, the implementation of social disclosure for each entity businesses in Indonesia is expected to create useful information so that business entities are not susceptible to problems outside of the economy (e.g., social and political issues). 


\section{Ml Macrothink \\ International Journal of Accounting and Financial Reporting \\ ISSN 2162-3082 2016, Vol. 6, No. 1}

\section{Conclusion}

Several conclusions can be drawn based on descriptions of social accounting and its application in Indonesia described as follows: (1) Social Accounting is still the pros and cons in the accounting world Indonesia, until now given the presence of pros and cons about the extent to which the company should be accountable to their social environment; (2) Social Accounting is defined by experts as a process to measure, manage and report on the impact of the interaction between multiple companies with their social environment; (3) Reporting and social disclosure in some developed countries is commonly done by large companies to describe the social concern to users of financial statements; (4) The practice of social disclosure firms in Indonesia is still very low because the company allegedly oriented to the Shareholder and debt holders only; (5) The role and application of social accounting need to be developed in Indonesia in order to encourage the creation of corporate social responsibility that are expected to minimize the social problems faced by business entities in Indonesia, so that the healthy investment climate and enduring economic stability.

\section{References}

Sonhadji, A. 1989 Akuntansi Sosial :Perananyadalammengukurtanggungjawab social perusahaan, suatutinjauananalitis, majalahakuntansi, no. 10 bulan Oktober

Adam, Carol, A, et.al .1997.CoorporateSosial Reporting Practices in Western Europe Legitimating Corporate behavior, Working Paper, Department of Accounting and Finance, University of Glasgow, England.

Davidson,1993. Environmental Financial disclosure : What to say and where to say it, Chemical Week, December edition, published by UMI database Journal, USA

Harahap Sofyan Safri, 1988, Sosio Economic Accounting (SEA) :Menyorotietikadantanggungjawab social perusahaan, Majalah Akuntansi No. 3 bulan Maret Hendriksen Eldon.S,1994, Accounting Theory, Third Edition, Mc.Hill, USA.

Ikatan Akuntan Indonesia (IAI), 1999.Standar Akuntansi Keuangan, buku satu, Salemba empat diterbitkan untuk IAI , Jakarta.

\section{Copyright Disclaimer}

Copyright for this article is retained by the author(s), with first publication rights granted to the journal.

This is an open-access article distributed under the terms and conditions of the Creative Commons Attribution license (http://creativecommons.org/licenses/by/3.0/). 